\title{
Knowledge Infrastructure, Service Sector, And Economic Growth In Africa
}

\author{
Amon O. Okpala, (E-mail: aokpala@uncfsu.edu), Fayetteville State University
}

\begin{abstract}
Economic theory and studies have theoretical and empirical evidence suggesting that countries which remain underdeveloped have consistently low levels of human capital, and a large agricultural sector. Of equal importance are the roles of the information technology and service sectors in improving economic growth and stability. This paper examined the extent to which nonindustrial factors, such as information technology, knowledge infrastructure, and the service sectors activities helped contribute to the economy of African nations. The results from the analysis of 38 African nations indicate the information infrastructure for index public expenditures on education and personal computers per 1,000 capita contributed significantly to economic productivity.
\end{abstract}

\section{INTRODUCTION}

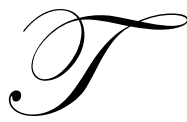

he first step in developing strategies for improving the life of the poor is to understand the policies and institutional factors that may lead to sustainable economic growth and development. Evidence shows that sustained economic growth depends on education, life expectancy, openness to international trade, institutional factors (especially evidence of a strong rule of law and absence of corruption), and human and physical capital stock. Traditional economic studies comprise theoretical and empirical evidence suggesting that countries which remain underdeveloped have consistently low levels of human capital; additionally, their investment in human capital is usually very low (Fayissa, 1996; and Khan \& Fayissa, 2000). Barro (1989) noted that countries who invest more in physical and human capital grow faster, given the existence of high initial human capital.

Of equal importance are the roles of information technology and the service sector in bringing about sustainable economic growth. According to the Human Development Report (2001), information technology can be a tool for growth because it can enhance human capabilities and development through employment creation and the productivity gains it generates. The service sector is beginning to play an increasing role in the global economy. To some extent, this increasing global role is due to the outsourcing of services by manufacturing firms during the last few decades as the firms sought out cheaper third world labor. According to Tomlinson \& Ndhlovu (2000), there has been a correlating rise in the service sector share of GDP in all regions - including developing nations. This lends more weight to the idea that we may be entering a new phase of economic era when service sector and the corresponding knowledge infrastructure could hold the key to sustainable economic growth and development.

This paper seeks to examine the extent to which the non-industrial factors (such as information technology, knowledge infrastructures, and the service sector activities) helped in contributing to the above-mentioned improvements. The mainstream view has often cast the service sector as of less importance when compared with manufacturing. If the service sector did contribute significantly to these improvements in the economies of Africa, measures must be taken to increase their influence. To accomplish that, this paper uses some statistical techniques to explore the interactions and clusters of sectors within different national settings. It will be argued that the service and knowledge infrastructure have a key role to play in the overall economic growth and development in African countries. 


\section{THE THEORETICAL MODEL}

The mainstream economic view has often cast the service sector as of less importance when compared with the role of capital stock, industry, and manufacturing, in shaping the growth of an economy. The neoclassical growth model as formulated by Robert Solow (1956) stressed the importance of saving and capital formation for economic growth. Using the Cobb-Douglas production function, Solow distinguished the sources of growth to be labor quantity and quality, capital stock and technology; expressed as:

$\mathrm{Y}=\mathrm{TK}^{\alpha} \mathrm{L}^{\beta}$

where Y - represents output or income;

$\mathrm{T}$ - the level of technology;

$\mathrm{K}$ - capital, and

L - labor.

Solow's neoclassical model was further augmented to include the human capital component as an additional explanatory variable to physical capital and labor. The modified growth equation is:

$\mathrm{Y}=\mathrm{TK}^{\alpha} \mathrm{L}^{\beta} \mathrm{H}^{\lambda}$

where $\mathrm{H}$ is human capital.

Noting the importance of information technology and the service sector in bringing about economic growth, this paper augments the model implicitly as shown below:

$\mathrm{GDP}=\mathrm{f}(\mathrm{KIV}, \mathrm{SV}, \mathrm{OV})$

where:

GDP represents the per capita income measured in purchasing power parities;

KIV represents different knowledge infrastructure variables: the Education Index (EDI), percentage of GDP spent on Public Education (PEXP); Internet Host per 10,000 people (INT); Personal Computers per 1,000 people (PC); and Information Infrastructure Index (ID).

SV represents two service variables: Value added as a percentage of GDP by the services sector (SERV); and Average annual percentage growth in services value added (AAGS)

OV represents other variables: Gross Capital Formation (GCF), value added as a percentage of GDP by Agriculture (AGRI), and value added as a percentage of industry (IND).

Alternatively, the regression equation can be explicitly written as:

$\mathrm{GDP}_{\mathrm{i}}=\beta_{0}+\beta_{1} \mathrm{EDI}_{\mathrm{i}}+\beta_{2} \mathrm{PEXP}_{\mathrm{i}}+\beta_{3} \mathrm{INT}_{\mathrm{i}}+\beta_{4} \mathrm{PC}_{\mathrm{i}}+\beta_{5} \mathrm{ID}_{\mathrm{i}}+\beta_{6} \mathrm{SERV}_{\mathrm{i}}+\beta_{7} \mathrm{GCP}_{\mathrm{i}}+\beta_{8} \mathrm{AGRI}_{\mathrm{i}}+\beta_{9} \mathrm{IND}_{\mathrm{i}}+\epsilon_{\mathrm{i}}$

Where $\beta$ 's represent the coefficient estimates and, represents the stochastic term. Two regression equations were used to analyze the impact of knowledge infrastructure and service sector variables on economic growth. All the regression equations were tested for the presence of multicollinearity: due to evidence of multicollinearity between the two service sector variables SERV and AAGS, they were not used in same regression equation. SERV was used in the regression equation result shown in Table 1, while AAGS was used in the results shown in Table 2. 


\section{DATA AND HYPOTHESES}

The data used in this study was obtained from the World Development Report, 2000 and 2001; and from the Human Development Report. The hypotheses developed here represent the prevailing economic theory as analyzed in the African context. First, we would expect the African countries with larger service sectors to be wealthier than those with more traditional agricultural sectors. Secondly, we would expect that the knowledge infrastructure variables (such as the education index, public education expenditure, availability of personal computers, and information infrastructure) would be positively correlated with productivity. Finally, (although not quite different from the first hypothesis), we expect that knowledge-based services are positive drivers of economic growth. Variables:

Dependent Variable: GDP - This variable is frequently used as a summary index of the relative economic well-being of people in different nations. It is commonly the most-used measure of the overall level of economic activity. When the official foreign exchange rates are used in converting the per capita GDP figures of less developed nations in US dollars, the numbers are sometimes exaggerated. Because nominal exchange rates do not always reflect international differences in relative prices, this paper uses the purchasing power parities (PPP), instead of the exchange rates, as the conversion factor. PPP is defined as the units of a foreign country's currency required to purchase an identical quantity of goods and services in the local developing market as one dollar would buy in the United States.

Explanatory Variables: Three groups of independent variables emerge from this analysis - Knowledge Infrastructure Variables, Service Variables, and other equally important variables.

\section{Group A}

\section{Knowledge Infrastructure Variables}

EDI: The Education Index measures a country's relative achievement in both adult literacy and combined primary, secondary, and tertiary gross enrolment. To calculate the EDI, first an index for adult literacy and one for combined gross enrolment are calculated. Then, these two indices are combined to create the education index, with two-thirds weight given to adult literacy and one-third weight given to combined gross enrolment (see World Development Report, 2000). Human development is an important means to technology development and at the same time, innovation in technology is an expression of human potential. Higher levels of education do make powerful contributions to technology creation and subsequently leads to the furthering of economic growth. Ahmed and Fayissa (2000) reported that improvements in educational achievement of the labor force affect economic growth because a more educated labor force is expected to be more skilled, adaptable, and entrepreneurial. For this paper, the education index is used as proxy variables for human development.

PEXP: Public Expenditure on Education as a percentage of GDP accounts for the public spending on public education plus subsidies to private education at primary, secondary, and tertiary levels. This variable captures government commitment to education. It is expected that PEXP and EDI may exhibit a strong correlation between themselves; and as such, may lead to a multicollinearity problem. The two variables will be analyzed in separate models to isolate their individual impacts.

INT: Refers to Internet Host per 10,000 people. These are computers connected directly to the world-wide web network. Because of measurement problems associated with the collecting of this data, many Internet Hosts shown for each country should be considered an approximation.

PC: Personal Computers per 1,000. These are estimates of number of self-contained computers designed to be used by a single person. In many developing countries, mainframe computers are used extensively, and thousands of users may be connected to a single mainframe computer. In such cases, the number of personal computers underestimates the total use of computers. 
ID: Information Infrastructure Index is a communication, information index. It includes the number of copies of newspapers published at least four times daily per 1,000 people, plus an estimated number of television sets in use per 1,000 people, plus all telephone lines that are connected to customers per 1,000, and the mobile telephones that are subscribed to customers per 1,000 people.

\section{Group B}

Service Variable(s)

Two variables are used to serve as proxies for the activities of the service sector: SERV and AAGS. Due to their close similarity in measurement, employing both SERV and AAGS in the same regression equation may result in a multicollinearity problem. As such, we will analyze their individual impact on economic growth by including each in a separate regression equation model.

SERV: Value added as a percentage of GDP by the service sector.

AAGS: This variable represents the average annual percentage growth in services value added. It measures the average annual growth rate of value added by the service sector to the economy.

\section{Group C \\ Other Variables}

These are other variables that do play an important role in explaining economic growth.

GCF: Gross capital formation consists of outlays on additions to the fixed assets of the economy plus net changes in the levels of inventories. Fixed assets include land improvements, plants, machinery, and equipment purchases; and the construction of buildings, roads, railways, and the like, including commercial and industrial buildings, offices, schools, hospitals, and private dwellings. According to neoclassical growth model, capital accumulation is the main source of economic growth. The faster the rate of capital accumulation occurs, the higher the growth rate of the economy and the faster the rate of new job creation. Also, it is important to indicate that every economy must save a certain proportion of its national income, either to replace worn-out capital, or to increase the stock of existing capital. In order to grow, new investments representing net additions to the capital stock is equally important. This analysis will use the additions to fixed assets plus net changes in inventory levels as proxies for capital. It is important to note here that the role of GCF may depend entirely on the existing level of capital stock in each African nation.

AGRI: Value added as percentage of GDP by the agricultural sector, which includes forestry and fishing, as well as cultivation of crops. Since many of the agricultural activities of developing nations are mainly for subsistence living, there is little exchange of agricultural production for money; this creates a problem with accurate measuring. As such, it reduces the reliability and comparability of agricultural contributions.

IND: Value added as a percentage of GDP by the industrial sector, which includes mining. Estimation Results:

As already indicated, the regression equation used in analyzing the relationship between per capita income and the variables mentioned in the previous section is shown below as:

$\mathrm{GDP}_{\mathrm{i}}=\beta_{0}+\beta_{1} \mathrm{EDI}_{\mathrm{i}}+\beta_{2} \mathrm{PEXP}_{\mathrm{i}}+\beta_{3} \mathrm{INT}_{\mathrm{i}}+\beta_{4} \mathrm{PC}_{\mathrm{i}}+\beta_{5} \mathrm{ID}_{\mathrm{i}}+\beta_{6} \mathrm{SERV}_{\mathrm{i}}+\beta_{7} \mathrm{GCP}_{\mathrm{i}}+\beta_{8} \mathrm{AGRI}_{\mathrm{i}}+\beta_{9} \mathrm{IND}_{\mathrm{i}}+\epsilon_{\mathrm{i}}$

Four different regression models were analyzed as illustrated in Tables $1 \& 2$. Due to the expected strong multicollinearity between the education index (EDI) and public expenditure on education (PEXP), the two variables were not included in same regression model. Also, including both SERV and AAGS in same equation model would 
likely result in serious multicollinearity: SERV was included in Models 1 and 4, while AAGS was included in Models 2 and 3.

The results from Regression Models 1 and 2 show that the relationship between the educational index and economic growth is statistically insignificant. Education index (EDI) was expected to play a significant role because a more knowledge-oriented economy (where adult literacy is improved), would positively impact productivity. Its lack of a significant impact in this study may be partly due to inadequate data, which is always an issue with studies on African nations. Gross capital formation and internet host per 10,000 people were found to be statistically insignificant in explaining changes in economic growth in all four regression models. As already indicated, Internet connections do not give adequate information regarding Internet usage in Africa because most users are not direct subscribers of the world-wide web network. They use the Internet services in local business centers that are connected directly to the world-wide web network. As such, the number of computers connected directly understates the total level of usage of Internet services. The regression results show that personal computers per 1,000 people (PC) to be positively related to economic growth. The estimates revealed that PC and economic growth were statistically significant at 1 percent and 5 percent levels. This supports the theoretical belief that the availability of personal computers in a nation will positively enhance economic growth.

The contribution of agricultural sector to economic growth was found to be statistically significant at the 10 percent level in Regression Models 1 and 2 and insignificant in Models 3 and 4. This lack of a consistent result regarding the contribution of agriculture to per capita GDP is not surprising when one factors in the subsistence nature of African traditional agriculture. Most traditional African agricultural output is for subsistence and not for exchange for money; as such, can not be reflected in the GDP figures.

The results from the four regression estimates show that the relationship between information infrastructure index (ID) and per capita GDP are positive and statistically significant at the one and five percentage levels of significance. This is consistent with the hypothesis that the information infrastructure, which includes most measurable communication and information data, should positively and significantly contribute to productivity growth in any economy.

The commitment of African government to public education appears to play an important role in the growth of the economy. Public expenditure on education as a percentage of GDP had a statistically significant and positive relationship in explaining changes in the growth of the economy. We observed mixed results with the service sectors variables - SERV and AAGS. Value added by the services as a percentage of the GDP (SERV) was found to be statistically insignificant, while the average annual percentage growth in services value added was positive and statistically significant at 10 percent in explaining changes in growth rates in the African economy. The African service sector is still at its infancy, and needs to grow more rapidly in order to play a significant impact on her economy. Although the results from this analysis are quite inconclusive, nevertheless, theoretical and empirical evidence from industrialized nations suggest that a vibrant service sector does contribute positively to the economy. As such, one would expect that as the service sector starts growing in Africa, it will gradually start playing a positive role in the economic growth of African nations.

\section{REFERENCE}

1. Barro, R. J. (1989), Fertility Choice in a Model of economic growth, Econometrica 57: 481-501.

2. Fayissa, Bichaka, Human Capital, Productivity, Research \& Development, Trade, and Economic Growth, Economica Internazionale, Genova, Italia.

3. Human Development Report (2001), Making new technology work for human development, New York: Oxford University Press, pp. 27-43.

4. Khan, J. Ahmed \& Fayissa, Bichaka, (2000), The role of human capital in the Economic growth of Pakistan, Proceedings of Third World Studies, 2000.

5. Solow, Robert, (1956), A contribution to the theory of economic growth, Quarterly Journal of Economics, pp. 65-94.

6. Tomlinson, Mark and Ndhlovu, (2000), African Economic Development: Do Services Matter? International Academy of African Business \& Development, 2001 Proceedings, pp. 114-121. 
Table 1 - Economic Growth (Per Capita GDP) and Explanatory Variables $(n=38)$

\begin{tabular}{lll}
\hline Explanatory Variables. & $\begin{array}{c}\text { Model 1 } \\
\text { Coeff. Estimates }\end{array}$ & $\begin{array}{c}\text { Model } 2 \\
\text { Coeff. Estimates }\end{array}$ \\
\hline Constant & & \\
Education Index (EDI) & 0.1126 & 0.1193 \\
& $(1.376)$ & $(1.532)$ \\
Gross Capital Formation (GCF) & 0.1123 & 0.0832 \\
& $(1.559)$ & 0.2221 \\
Information Infrastructure Index (ID) & 0.1935 & $(2.567)^{* *}$ \\
Value added by industry as \% of GDP (IND) & $(2.305)^{* *}$ & 0.1976 \\
& & $(2.801)^{*}$ \\
Internet Host/10,000 people (INT) & 0.2089 & 0.0154 \\
& $(2.538)^{* *}$ & $(0.095)$ \\
Personal Computer/1,000 people (PC) & 0.0192 & 0.595 \\
& $(0.118)$ & $(3.218)^{*}$
\end{tabular}

Public Expenditure on Education as \% GDP (PEXP)

Value added by Services as a $\%$ of GDP (SERV) 0.0682 $(0.751)$

Value added by agriculture as $\%$

$\begin{array}{ll}0.1143 & 0.1220 \\ (1.749)^{* * *} & (1.897)^{* * * *} \\ & 0.1011 \\ & (1.311) \\ & \\ 0.8855 & 0.8898 \\ 0.8539 & 0.8594 \\ 28.0374 & 29.2749\end{array}$

Adjusted $\mathrm{R}^{2}$ of GDP (AGRI)

Average annual \% growth in services Value added (AAGS)

F-Statistics

t-ratios in parentheses.

(*) significant at $\rho \leq .01$

(**) significant at $\rho \leq .05$

$(* * *)$ significant at $\rho \leq .1$ 
Table 2. - Economic Growth (Per Capita GDP) and Explanatory Variables. $(n=38)$

\begin{tabular}{|c|c|c|}
\hline Explanatory Variable. & $\begin{array}{c}\text { Model 3. } \\
\text { Coeff. Estimates }\end{array}$ & $\begin{array}{c}\text { Model } 4 . \\
\text { Coeff. Estimates }\end{array}$ \\
\hline \multicolumn{3}{|l|}{ Constant } \\
\hline Gross Capital Formation (GCF) & $\begin{array}{l}0.0507 \\
(0.746)\end{array}$ & $\begin{array}{l}0.104 \\
(1.559)\end{array}$ \\
\hline Information Infrastructure Index (ID) & $\begin{array}{l}0.2534 \\
(3.545)^{*}\end{array}$ & $\begin{array}{l}0.2100 \\
(2.902)^{*}\end{array}$ \\
\hline \multicolumn{3}{|l|}{ Education Index (EDI) } \\
\hline Value added by industry as \% of GDP (IND) & $\begin{array}{l}0.1753 \\
(2.788)^{* *}\end{array}$ & $\begin{array}{l}0.1733 \\
(2.226)^{* *}\end{array}$ \\
\hline Internet Host/10,000 people (INT) & $\begin{array}{l}0.0953 \\
(0.655)\end{array}$ & $\begin{array}{l}0.019 \\
(0.125)\end{array}$ \\
\hline Personal Computer/1,000 people (PC) & $\begin{array}{l}0.4387 \\
(2.549)^{* *}\end{array}$ & $\begin{array}{l}0.5548 \\
(23.083)^{*}\end{array}$ \\
\hline $\begin{array}{l}\text { Public Expenditure on Education } \\
\text { as \% of GDP (PEXP) }\end{array}$ & $\begin{array}{l}0.2352 \\
(3.309)^{*}\end{array}$ & $\begin{array}{l}0.2053 \\
(2.666)^{* *}\end{array}$ \\
\hline $\begin{array}{c}\text { Average annual \% growth in services } \\
\text { value added (AAGS) }\end{array}$ & $\begin{array}{l}0.1418 \\
(2.066)^{* *}\end{array}$ & \\
\hline $\begin{array}{l}\text { Value added by agriculture as \% } \\
\text { of GDP (AGRI) }\end{array}$ & $\begin{array}{l}0.0841 \\
(1.438)\end{array}$ & $\begin{array}{l}0.0812 \\
(1.304)\end{array}$ \\
\hline Value added by service as a $\%$ of GDP (SERV) & & $\begin{array}{l}0.0505 \\
(0.606)\end{array}$ \\
\hline $\begin{array}{l}\mathrm{R}^{2} \\
\text { Adjusted } \mathrm{R}^{2} \\
\text { F-Statistics }\end{array}$ & $\begin{array}{l}0.9135 \\
0.8897 \\
38.2778\end{array}$ & $\begin{array}{l}0.9021 \\
0.8750 \\
33.383\end{array}$ \\
\hline $\begin{array}{l}\text { t-ratios in parentheses } \\
(*) \text { significant at } \rho \leq .01 \\
(* *) \text { significant at } \rho \leq .05 \\
(* * *) \text { significant at } \rho \leq .10\end{array}$ & & \\
\hline
\end{tabular}




\section{NOTES}

